\title{
Electroslag Refining of CrNiMoWMnV Ultrahigh-Strength Steel
}

\author{
Mohammed Ali1,2*, Mamdouh Eissa' ${ }^{2}$, Hoda El Faramawy'2, David Porter ${ }^{1}$, Jukka Kömi1, \\ M. F. El-Shahat ${ }^{3}$, Taha Mattar $^{2}$
}

${ }^{1}$ Materials Engineering and Production Technology, University of Oulu, Oulu, Finland

${ }^{2}$ Steel Technology Department, Central Metallurgical Research and Development Institute, Cairo, Egypt

${ }^{3}$ Chemistry Department, Ain Shams University, Cairo, Egypt

Email: mohammedsalah2020@gmail.com

How to cite this paper: Ali, M., Eissa, M., El Faramawy, H., Porter, D., Kömi, J., El-Shahat, M.F. and Mattar, T. (2017) Electroslag Refining of CrNiMoWMnV Ultrahigh-Strength Steel. Journal of Minerals and Materials Characterization and Engineering, 5, 385-407.

https://doi.org/10.4236/immce.2017.56032

Received: October 26, 2017

Accepted: November 27, 2017

Published: November 30, 2017

Copyright $\odot 2017$ by authors and Scientific Research Publishing Inc. This work is licensed under the Creative Commons Attribution International License (CC BY 4.0).

http://creativecommons.org/licenses/by/4.0/

\begin{abstract}
Increasing demands for ultrahigh-strength steels in commercial as well as military applications have raised interest in finding alternatives to the high-cost high-alloyed steel and super-alloys currently used, e.g. the use of economic low-alloy compositions processed via low-cost air induction melting and electroslag refining (ESR). In this work the yield of alloying elements and the removal of the impurities nitrogen, sulphur and phosphorus as a result of electroslag refining (ESR) in a newly developed CrNiMoWMnV ultrahigh-strength steel (UHSS) have been studied in relation to their activities in the molten metal pool. Six experimental heats of CrNiMoWMnV UHSS with different chemical compositions were designed, melted in an induction furnace (IF) and refined using ESR. This was followed by hot forging of the ingots at $1100^{\circ} \mathrm{C}$ to $950^{\circ} \mathrm{C}$. ESR using a $\mathrm{CaF}_{2}-\mathrm{CaO}-\mathrm{Al}_{2} \mathrm{O}_{3}$ slag system led to a high yield in $\mathrm{Cr}, \mathrm{Ni}, \mathrm{Mo}, \mathrm{W}, \mathrm{Mn}$ and $\mathrm{V}$, while the yield of $\mathrm{Si}$ is low. The desulphurization of all six UHSS grades was pronounced with most of the sulphur removed either to the slag or by gas reactions. The degree of dephosphorization was only $5 \%$ irrespective of the steel composition. On the other hand, denitrification (removal of nitrogen) was achieved. It ranged from $8 \%$ to $63 \%$ depending on the steel composition. The yield of the alloying elements and removal of impurities from the steel during ESR depends on the chemical and physical properties of the ESR slag and the activity of the elements in the molten state, taking into account elemental interactions.
\end{abstract}

\section{Keywords}

Ultrahigh-Strength Steel, Electroslag Refining, Alloying Elements, Impurities, Activity 


\section{Introduction}

There is no generally accepted definition of what constitutes ultrahigh-strength in structural steels as it depends on the field of application. According to Philip [1] [2] it implies a yield strength exceeding $200 \mathrm{ksi}$, i.e. $1380 \mathrm{MPa}$, but more recently the term has been applied to steels with a yield strength of about $900 \mathrm{MPa}$, and above [3]. Common to all ultrahigh-strength steels is the need to have a low level of impurities, such as sulfur, phosphorous and non-metallic inclusions (NMI), as well as freedom from defects like voids and cracks, and homogeneous compositions within narrow tolerances [4].

The electroslag refining (ESR) process is one of the most important secondary refining processes owing to its relatively low production cost, low capital investment and ability to produce high quality steel with desired chemistry and homogenous structure. It is also found that the ductility, impact toughness and transition characteristics and corrosion resistance are remarkably improved due to the pronounced effect of ESR on the removal of NMI. ESR has also been shown to enhance strength as a result of the grain refinement resulting from the addition of some inoculants during the ESR process [4] [5] [6].

In the ESR process, the slag plays different roles: as a heating source, protection of the melt from oxidation and facilitation of chemical refining which has the main powerful effect on the yield of alloying elements, besides desulphurization and removal of exogenous non-metallic inclusions [7] [8].

It is important to use reducing slags to control the oxygen content of the melt to low levels, which leads to high yields of the alloying elements in the final product.

Sulphur enhances the machinability of steel but has a detrimental effect on the properties of most other steel properties such as ductility, impact toughness and weldability, so, in the case of structural steels especially those with ultrahigh-strength, it must be reduced to a minimum. In ESR, two reactions result in the removal of sulphur from the steel; those at the slag/metal and slag/gas interfaces as given in Equations (1) and (2), respectively: [4] [9] [10]

$$
\begin{gathered}
{[\mathrm{S}]_{\text {Metal }}+\left(\mathrm{O}^{2-}\right)_{\text {Slag }} \leftrightarrow\left(\mathrm{S}^{2-}\right)_{\text {Slag }}+[\mathrm{O}]_{\text {Metal Drop }}} \\
3 / 2 \mathrm{O}_{2}(\mathrm{~g})+\left(\mathrm{S}^{2-}\right)_{\text {Slag }} \leftrightarrow\left(\mathrm{O}^{2-}\right)_{\text {Slag }}+\mathrm{SO}_{2(\mathrm{~g})}
\end{gathered}
$$

As indicated in Equation (1), sulphur transfer from the molten metal to the molten slag depends on the amount and activity of oxygen ions in the metal and slag. Decreasing the activity of oxygen in the metal and increasing it in the slag enhances the desulphurization process. Hayashi et al. [11] gave another mechanism for the desulphurization process in which the removal of sulphur increases by dissolution with an $\mathrm{O}^{-}$ion thus supplying oxides in slag as follows:

$$
1 / 2 \mathrm{~S}_{2(\mathrm{~g})}+\left(\mathrm{M}_{\mathrm{x}} \mathrm{O}\right)_{\text {slag }} \leftrightarrow 1 / 2 \mathrm{O}_{2(\mathrm{~g})}+\left(\mathrm{M}_{\mathrm{x}} \mathrm{S}\right)_{\text {slag }}
$$

Vaish et al. [4] and Eissa et al. [12] stated that most sulphur transfer occurs from the slag to the atmosphere, but that depends mainly on the sulphur transfer 
from the metal to the slag as given by Equation (1).

Phosphorus increases strength and hardness, but has a detrimental effect on ductility and impact toughness so it must be minimized. The removal of phosphorus is based on the oxidation of phosphorus followed by absorption by the slag. This process depends mainly on the activity and partial pressure of oxygen and the following equation can represent the dephosphorization process: [13] [14] [15] [16]

$$
2[\mathrm{P}]_{\text {Metal }}+5[\mathrm{O}]_{\text {Metal }}+3\left(\mathrm{O}^{2-}\right)_{\text {Slag }} \leftrightarrow 2\left(\mathrm{PO}_{4}^{3-}\right)_{\text {Slag }}
$$

Depending on its location in the steel, nitrogen can be either beneficial or detrimental to mechanical properties. In the form of nitrides like VN nitrogen can enhance grain refinement giving higher ductility and toughness [17] [18] [19]. [20] Nitrogen can also exist in interstitial solid solution like carbon but with a higher solubility than carbon. As nitrogen can diffuse easily in the iron matrix at low temperatures, this reduces the cold forging performance. Nitrogen may also lead to the formation of porosity and blowholes [20] [21] [22].

Nitrogen dissolves in the molten slag either in the form of free nitride $\left(\mathrm{N}^{3-}\right)$ or as an incorporated nitride $\left(\mathrm{N}^{-}\right)$depending on the slag composition. In a basic slag system, nitrogen reacts with free oxygen $\left(\mathrm{O}^{2-}\right)$ as a free nitride as given in Equation (5). However, in an acidic slag system of low basicity the nitrogen reacts with non-bridging oxygen $\left(\mathrm{O}^{-}\right)$as an incorporated nitride as given by Equation (6) [23] [24] [25] [26] [27].

$$
\begin{gathered}
1 / 2 \mathrm{~N}_{2(\mathrm{~g})}+3 / 2\left(\mathrm{O}^{2-}\right)_{\text {Slag }} \leftrightarrow\left(\mathrm{N}^{3-}\right)_{\text {Slag }}+3 / 4 \mathrm{O}_{2(\mathrm{~g})} \\
1 / 2 \mathrm{~N}_{2(\mathrm{~g})}+2\left(\mathrm{O}^{-}\right)_{\text {Slag }} \leftrightarrow\left(\mathrm{N}^{-}\right)_{\text {Slag }}+1 / 2\left(\mathrm{O}^{2-}\right)_{\text {Slag }}+3 / 4 \mathrm{O}_{2(\mathrm{~g})}
\end{gathered}
$$

Removal of nitrogen in the ESR process may take place by two means: physical removal of nitride inclusions by entrainment in the slag or by dissolution depending on the capacity of the ESR slag, the carbon content of the system, and the presence or absence of strong nitride formers, according to one of the following reactions at the molten metal-slag interface:

$$
\begin{aligned}
& {[\mathrm{N}]_{\text {Metal }}+3 / 2\left(\mathrm{O}^{2-}\right)_{\text {Slag }} \leftrightarrow }\left(\mathrm{N}^{3-}\right)_{\text {Slag }}+3 / 2[\mathrm{O}]_{\text {Metal }} \\
& \mathrm{N}_{2(\mathrm{~g})}+\mathrm{C}^{2-}{ }_{\text {(Slag) }} \rightarrow \mathrm{CN}_{2}^{2-} \text { (Slag) }
\end{aligned}
$$

Lower activity of oxygen in the metal and higher in the slag leads to an enhancement of denitrification.

During the electroslag refining process the following steps take place. Increasing the oxygen activity, oxidation rate and decreasing the reduction rate lead to high losses of alloying elements or formation of inclusions [28].

Electrode Oxidation: $\mathrm{x}[\mathrm{M}]+\mathrm{y} / 2 \mathrm{O}_{2} \rightarrow\left(\mathrm{M}_{\mathrm{x}} \mathrm{O}_{\mathrm{y}}\right)$

Reduction of Oxides: $\left(\mathrm{M}_{\mathrm{x}} \mathrm{O}_{\mathrm{y}}\right) \rightarrow \mathrm{x}[\mathrm{M}]+\mathrm{y}[\mathrm{O}]$

Formation of inclusions in the produced ingot: $x[R]+y[O] \rightarrow\left(\mathrm{R}_{x} \mathrm{O}_{\mathrm{y}}\right)$ where, M: Metal to be melted (Usually a transition metal) 
$\mathrm{R}$ : alloying element with high affinity for oxygen such as $\mathrm{Si}, \mathrm{Al}$ or $\mathrm{Ti}$

The carbon content of the steel can be increased during electroslag refining as a result of carbon in the molten slag, which increases during the pre-fusion process or from additives by means of carbide ions oxidized to carbon.

High oxygen activity in the molten slag leads to oxidation of a high percent of $\mathrm{Si}$ in the consumable electrode with the formation of silica as shown in Equation (9). Then $\mathrm{SiO}_{2}$ reacts with $\mathrm{CaO}$ to form the very stable calcium silicate in the slag produced, thereby lowering the silica activity and the yield of Si in the steel produced [28].

$$
[\mathrm{Si}]+2(\mathrm{FeO}) \leftrightarrow\left(\mathrm{SiO}_{2}\right)+2[\mathrm{Fe}]
$$

Mattar [29] showed that slag consisting of $70 \% \mathrm{CaF}_{2}, 15 \% \mathrm{CaO}$ and $15 \% \mathrm{Al}_{2} \mathrm{O}_{3}$ (a 70-15-15 slag) not only has a high desulphurizing power but also a remarkable effect on the number density, size and distribution of nonmetallic inclusions in the steel matrix.

This work aims at studying the effect of the ESR process on the yield of valuable alloying elements, together with $\mathrm{S}$ and $\mathrm{P}$ removal and the possibility of $\mathrm{N}$ removal for CrNiMoWMnV low alloyed potential ultrahigh-strength steels (UHSS) when using the above 70-15-15 slag system. There are only a limited number of studies of the effect of primary chemical composition on the final chemical composition of the produced ingot [30]. Therefore the aim of this work is to study the relationships between the activities of alloying elements and impurities in the molten metal and their effects on the yields of alloying elements and the removal of impurities.

\section{Experimental Work}

Six experimental heats of steel with different chemical compositions were designed to satisfy the targeted properties. Low to medium C content was used to improve weldability, $\mathrm{Mn}, \mathrm{Si}$ and $\mathrm{Ni}$ were used to stabilize the austenite phase and enhance toughness, $\mathrm{Cr}$ was added to enhance strength and hardenability, Mo to enhance hardenability, $\mathrm{W}$ to enhance strength and wear resistance, and V to increase toughness. The heats were made in the Steel Technology Department, Central Metallurgical Research and Development Institute (CMRDI), Egypt by melting the scrap, ferroalloys and nickel alloy shown in Table 1 in an air induction furnace lined with spinel. The chemical composition of the scrap was analyzed using Optical Emission Spectrometry (SPECTRO analytical instrument) while ferroalloys and nickel alloy were analyzed using a Philips PW $1410 \mathrm{X}$-Ray Spectrometer with PW 1390 channel control After the chemical composition and the temperature of the molten steel were adjusted, the molten metal was tapped at $1560^{\circ} \mathrm{C}-1580^{\circ} \mathrm{C}$ into a steel mould $250 \mathrm{~mm}$ long and $70 \mathrm{~mm}$ in diameter. Samples, $10 \mathrm{~mm}$ thickness and $70 \mathrm{~mm}$ in diameter, were cut from the bottom of the steel ingots after discarding $20 \mathrm{~mm}$ from the bottom and used for determination the chemical composition of the steels. The surfaces of all the ingots were cleaned prior to further processing. 
Table 1. Chemical composition of charged materials.

\begin{tabular}{|c|c|c|c|c|c|c|c|c|c|c|c|c|c|}
\hline \multirow{2}{*}{$\begin{array}{l}\text { Charging } \\
\text { Materials }\end{array}$} & \multicolumn{13}{|c|}{ Chemical composition, wt.\% } \\
\hline & $\mathrm{C}$ & $\mathrm{Si}$ & $\mathrm{Mn}$ & $\mathrm{Cr}$ & $\mathrm{Ni}$ & $\mathrm{V}$ & $\mathrm{W}$ & Mo & $\mathrm{Al}$ & $\mathrm{P}$ & $S$ & $\mathrm{Ca}$ & $\mathrm{Fe}$ \\
\hline Scrap 1 & 0.3 & 0.30 & 1.08 & - & - & 0.007 & - & - & - & 0.030 & 0.022 & - & Bal. \\
\hline Scrap 2 & 0.1 & 0.17 & 0.35 & - & - & 0.009 & - & - & - & 0.028 & 0.021 & - & Bal. \\
\hline LC Fe-Mn & 0.3 & 2.3 & 80.6 & - & - & 0.035 & - & - & - & & - & 0.31 & 16.1 \\
\hline $\mathrm{Fe}-\mathrm{Si}$ & - & 72.1 & 0.39 & - & - & 0.04 & - & - & 1.5 & & - & 1.4 & 24.0 \\
\hline $\mathrm{Fe}-\mathrm{V}$ & - & 2.5 & 0.26 & - & - & 77.5 & - & - & 3.03 & & - & 0.2 & 16.0 \\
\hline LC Fe-Cr & - & 2.9 & 0.5 & 65 & - & 0.2 & - & - & 0.65 & & - & - & 30 \\
\hline Fe-Mo & - & 2.0 & 0.21 & - & 0.36 & 0.15 & - & 55.55 & - & & - & - & 41.5 \\
\hline $\mathrm{Fe}-\mathrm{W}$ & - & - & 1.0 & - & - & 0.12 & 69 & 0.9 & - & & - & 2.5 & 26 \\
\hline $\mathrm{Ni}$ alloy & - & 0.9 & 0.02 & - & 97.6 & 0.01 & - & - & - & & - & 0.4 & 0.07 \\
\hline
\end{tabular}

After reheating to $1100^{\circ} \mathrm{C}$ and holding for one hour, half of the steel ingots were forged into steel bars with cross sections $28 \times 30 \mathrm{~mm}$ to produce a consumable electrode for the ESR process. The forging start temperature was about $1100^{\circ} \mathrm{C}$ while the finish temperature was adjusted to be $950^{\circ} \mathrm{C}$.

Fused synthetic slag was prepared giving stable slag components with a minimum tendency to moisture pick up in order to minimize the hydrogen content of the steel produced. The slag composition by weight was about $70 \% \mathrm{CaF}_{2}, 15 \%$ $\mathrm{Al}_{2} \mathrm{O}_{3}$ and $15 \% \mathrm{CaO}$. It was produced in a $10 \mathrm{~kg}$ pilot plant using submerged electric arc furnace. The furnace was operated at an average of $480 \mathrm{~A}$ and $35 \mathrm{~V}$. The furnace wall and bottom were rammed with a thick magnesite layer and another layer of carbon paste. After completing the melting process, the fused slag was cast into metallic moulds of $100 \mathrm{~mm}$ inner diameter and $250 \mathrm{~mm}$ height. The product was left to cool to room temperature in the mold and then crushed to an appropriate size $(<20 \mathrm{~mm})$ for use in the ESR refining process. Representative samples of the slag were subjected to chemical analysis using XRF.

At the start of ESR process, a starting disc $28 \mathrm{~mm} \times 10 \mathrm{~mm} \times 30 \mathrm{~mm}$ was cut from the base material of the consumable electrode and put on the water cooled copper base plate to protect it.

The ESR process was initiated with an exothermic capsule composed of $54 \mathrm{~g}$ $\mathrm{Al}$ powder and $160 \mathrm{~g}$ of mill scale $\mathrm{Fe}_{2} \mathrm{O}_{3}$ and a small amount of $\mathrm{Mg}$. Such a composition gives the stoichiometric composition needed for the exothermic reaction, which gives the heat for starting the process.

$$
2 \mathrm{Al}+\mathrm{Fe}_{2} \mathrm{O}_{3} \leftrightarrow 2 \mathrm{Fe}+\mathrm{Al}_{2} \mathrm{O}_{3}+\text { Heat }
$$

A small amount of aluminum corresponding to about $0.1 \%$ of the total weight of the consumable electrode added as a deoxidant during the ESR process to avoid or reduce the loss of alloying elements. A water-cooled crystallizer was used as the vessel for melting and solidifying the steel. The ESR machine consists 
of a power supply with regulation parts for controlling current and voltage, Figure 1. The electrical parameters of the ESR process are given in Table 2. The refined steel ingots were subjected to the same forging process that was used on the base ingots.

X-ray Fluorescence (XRF) analysis was made using a Philips PW 1410 X-Ray Spectrometer with PW 1390 channel control to determine the percentage of all chemical constituents in the synthetic fused slags before and after ESR. A LECO CS444 (C.S-Mat 650) was used to determine the C content in slag before and after the ESR Process. Optical Emission Spectrometry (SPECTRO analytical instrument) was used to determine the chemical composition of the steel ingots after different stages. About $1 \mathrm{~g}$ of small chips of steel and $1 \mathrm{~g}$ of slag powder were analyzed for $\mathrm{N}$ using an ELTRA ONH 2000 and the Kjeldahl method [31] respectively. Oxygen content was analyzed at the company Outokumpu in Finland using LECO combustion analysis for a sample cut from the forged bar.

\section{Results and Discussion}

\subsection{Effect of ESR Process on the Yield of Alloying Elements}

The chemical composition of the fused slag and the six grades of UHSS steel before and after electroslag refining is given in Table 3 and Table 4 respectively.

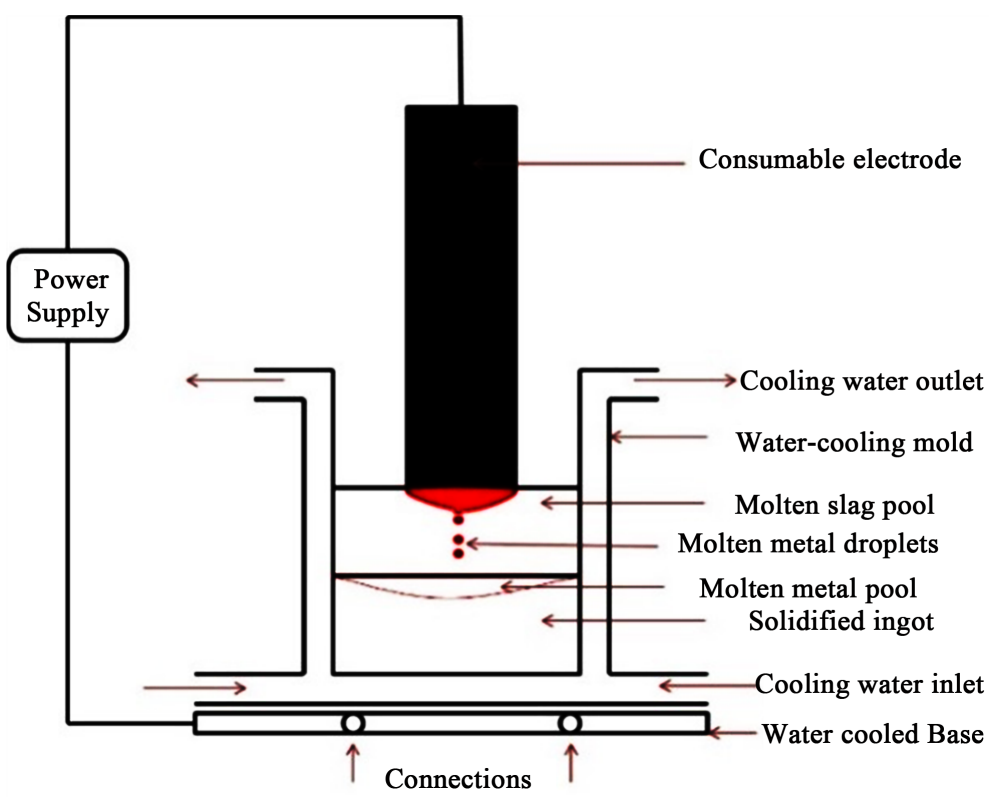

Figure 1. A schematic diagram of the ESR process.

Table 2. Electrical parameters of the ESR process.

\begin{tabular}{cc}
\hline Item & Value \\
\hline Working current & $1200-1500 \mathrm{~A}$ \\
Working voltage & $30-40 \mathrm{~V}$ \\
Melting Rate & $4.63 \mathrm{gm} / \mathrm{sec}$ \\
\hline
\end{tabular}


Table 3. Chemical composition of synthetic pre-fused slag.

\begin{tabular}{lcccccccccccc}
\hline & \multicolumn{8}{c}{ Chemical constituent, wt\% } \\
$\begin{array}{c}\text { Synthetic } \\
\text { fused slag }\end{array}$ & $\mathrm{CaF}_{2}$ & $\mathrm{CaO}$ & $\mathrm{Al}_{2} \mathrm{O}_{3}$ & $\mathrm{SiO}_{2}$ & $\mathrm{Cr}_{2} \mathrm{O}_{3}$ & $\mathrm{NiO}$ & $\mathrm{MnO}$ & $\mathrm{TiO}_{2}$ & $\mathrm{P}_{2} \mathrm{O}_{5}$ & $\mathrm{SO}_{3}$ & $\mathrm{Fe}_{2} \mathrm{O}_{3}$ \\
& $62-70$ & $12-15$ & $15-20$ & $1.7-2$ & $0-0.037$ & $0-0.184$ & $0-0.023$ & $0.13-0.15$ & 0.01 & $0.1-0.2$ & $0.11-0.13$ \\
\hline
\end{tabular}

Table 4. Chemical composition of steel before and after ESR process.

\begin{tabular}{|c|c|c|c|c|c|c|c|c|c|c|c|c|c|c|c|c|c|}
\hline \multirow{2}{*}{$\begin{array}{l}\text { Heat } \\
\text { No. }\end{array}$} & \multirow{2}{*}{ Process } & \multicolumn{16}{|c|}{ Chemical Composition, wt\% } \\
\hline & & $\mathrm{C}$ & $\mathrm{Cr}$ & $\mathrm{Ni}$ & Mo & $\mathrm{W}$ & $\mathrm{Mn}$ & $\mathrm{Si}$ & $\mathrm{V}$ & $\mathrm{Ti}$ & $\mathrm{Nb}$ & $\mathrm{Cu}$ & $\mathrm{Al}$ & $\mathbf{P}$ & $S$ & $\mathrm{~N}$ & $\mathrm{O}$ \\
\hline \multirow{2}{*}{ A } & IF & 0.299 & 2.32 & 2.34 & 0.324 & 1.21 & 0.699 & 0.709 & 0.075 & 0.001 & 0.001 & 0.017 & 0.009 & 0.0194 & 0.024 & 0.013 & 0.01381 \\
\hline & ESR & 0.320 & 2.18 & 2.31 & 0.307 & 1.14 & 0.636 & 0.641 & 0.072 & 0.001 & 0.001 & 0.020 & 0.060 & 0.0180 & 0.013 & 0.011 & 0.00353 \\
\hline \multirow{2}{*}{$B$} & IF & 0.250 & 1.57 & 3.27 & 0.301 & 1.46 & 0.603 & 0.782 & 0.072 & 0.001 & 0.002 & 0.015 & 0.016 & 0.0200 & 0.019 & 0.020 & 0.01704 \\
\hline & ESR & 0.305 & 1.57 & 3.13 & 0.299 & 1.26 & 0.567 & 0.651 & 0.072 & 0.002 & 0.002 & 0.013 & 0.043 & 0.0196 & 0.012 & 0.016 & 0.01344 \\
\hline & IF & 0.251 & 2.40 & 2.49 & 0.324 & 1.34 & 0.566 & 0.893 & 0.087 & 0.002 & 0.001 & 0.018 & 0.009 & 0.0190 & 0.025 & 0.020 & 0.0109 \\
\hline & ESR & 0.286 & 2.37 & 2.45 & 0.329 & 1.23 & 0.527 & 0.809 & 0.085 & 0.003 & 0.001 & 0.020 & 0.058 & 0.0186 & 0.014 & 0.018 & 0.0069 \\
\hline & IF & 0.145 & 1.73 & 4.44 & 0.312 & 1.33 & 0.409 & 0.511 & 0.067 & 0.002 & 0.002 & 0.016 & 0.009 & 0.0180 & 0.022 & 0.022 & 0.01166 \\
\hline & ESR & 0.176 & 1.65 & 4.35 & 0.323 & 1.24 & 0.350 & 0.310 & 0.062 & 0.001 & 0.001 & 0.020 & 0.043 & 0.0179 & 0.017 & 0.015 & 0.00625 \\
\hline & IF & 0.092 & 2.07 & 3.11 & 0.303 & 1.07 & 0.688 & 0.473 & 0.052 & 0.001 & 0.001 & 0.011 & 0.008 & 0.0170 & 0.019 & 0.020 & 0.02352 \\
\hline & ESR & 0.144 & 2.06 & 3.09 & 0.311 & 1.00 & 0.607 & 0.342 & 0.051 & 0.001 & 0.001 & 0.010 & 0.044 & 0.0168 & 0.013 & 0.008 & 0.00931 \\
\hline & IF & 0.057 & 3.50 & 1.01 & 0.453 & 1.79 & 0.327 & 0.876 & 0.084 & 0.001 & 0.001 & 0.016 & 0.013 & 0.0220 & 0.023 & 0.033 & 0.00595 \\
\hline & ESR & 0.066 & 3.21 & 1.01 & 0.456 & 1.62 & 0.319 & 0.425 & 0.075 & 0.001 & 0.001 & 0.017 & 0.029 & 0.0219 & 0.014 & 0.021 & 0.01117 \\
\hline
\end{tabular}

IF: Ingot produced from induction furnace; ESR: Ingot chemistry following ESR.

The following steps are pertinent to the oxidation of alloying elements in ESR: As the temperature of the slag pool rises above the melting point of the metal, droplets melt off the tip of the consumable electrode and fall through the slag pool. As the temperature of the falling droplet is fairly high, the oxidation of alloying elements can take place depending on their affinity to oxygen. For elements with a very high affinity to oxygen, the oxidation reaction may be take place with the atmospheric oxygen and its oxidation rate depend mainly on the surface area exposure to the atmospheric oxygen so by increasing the melting rate the oxidation reaction will be increased. The major part of the oxidation process for the elements with lower oxygen affinity take place during the transfer of metal droplet through the molten slag by diffusion of oxygen, which depends on the physical properties of the slag. Increasing wetting of the falling droplets with the slag, i.e., decreasing interfacial tension, leads to the formation of a protective layer that reduces the diffusion of oxygen towards the metal droplet and the oxidation rate and hence increasing the yield of the alloying element. Increasing slag viscosity leads to a reduction of oxygen transport towards the metal droplets.

At the slag/metal interface, slag can either oxidize the components of the metallic melt, e.g. Mn, and form cations which are then incorporated into the slag 
or vice-versa, i.e. cations are reduced and incorporated it into the molten metal pool. These reactions are indicated by the following reactions [32].

$$
\begin{gathered}
\mathrm{Mn}_{\text {met }}+2 \mathrm{O}^{-} \rightarrow \mathrm{Mn}^{2+}+2 \mathrm{O}^{2-}(\text { Oxidation reaction }) \\
\left.\mathrm{Mn}^{2+}+2 \mathrm{Fe}^{2+} \rightarrow \mathrm{Mn}_{\text {met }}+2 \mathrm{Fe}^{3+} \text { (Electron Exchange }\right)
\end{gathered}
$$

The direction of the equation depends on the oxygen potential which given by either the activity of oxidizing anions or activity of reducing cations and the activity of $\mathrm{Mn}$ in the melt pool.

From the chemical composition of the six grades of UHSS before and after ESR, the effect of the refining process on the stability of the alloying elements $\mathrm{C}$, $\mathrm{Cr}, \mathrm{Ni}, \mathrm{Mo}, \mathrm{W}, \mathrm{Mn}, \mathrm{Si}$ and $\mathrm{V}$ in steels under investigation was studied, as shown in Figure 2. It is observed that electroslag refining using synthetic fused 70-15-15 slag is remarkably effective in attaining high yields of the alloying elements; viz., Cr, Ni, Mo, W, Mn and V. This may be attributed to the inhibition of oxygen transfer from atmospheric air to the molten metal due to the high viscosity and lower interfacial tension of the slag, which provides a protective layer against oxygen attack on the molten metal droplets. Also, the addition of $\mathrm{Al}$ deoxidant reduces the oxygen activity and the oxidation kinetics of the alloying elements in the slag. Mo is increased as a percentage in steels $\mathrm{C}, \mathrm{D}, \mathrm{E}$ and $\mathrm{F}$ due to its extremely low interaction coefficient with oxygen (see Table 5) and its less negative free energy of oxidation combined with the fact that the impurities $\mathrm{S}, \mathrm{N}$ and $\mathrm{P}$ and other alloying elements like $\mathrm{Si}, \mathrm{Mn}, \mathrm{V}$ and $\mathrm{Cr}$ are removed. These results are in good agreement with those obtained by Burak et al. [33] who concluded that the losses of $\mathrm{Cr}$, Mo and $\mathrm{W}$ alloying elements do not exceed $10 \%$ and also those obtained by Mattar et al. [29] who concluded that the increment in the non oxidizable element like $\mathrm{Mo}$ and $\mathrm{W}$ in the produced ingot could be attributed to the losses oxidizable elements such as $\mathrm{Si}, \mathrm{V}, \mathrm{Mn}$ and $\mathrm{Cr}$. The net change in the elements or losses are calculated according to the following expression:

Table 5. Activity interaction coefficient $e_{i}^{j}$ of all constituents in the molten steel [34].

\begin{tabular}{ccccccccccccccc}
\hline$e_{i}^{j}$ & $\mathrm{C}$ & $\mathrm{Cr}$ & $\mathrm{Ni}$ & $\mathrm{Mo}$ & $\mathrm{W}$ & $\mathrm{Mn}$ & $\mathrm{Si}$ & $\mathrm{V}$ & $\mathrm{Cu}$ & $\mathrm{Al}$ & $\mathrm{P}$ & $\mathrm{S}$ & $\mathrm{N}$ & $\mathrm{O}$ \\
\hline $\mathrm{C}$ & 0.124 & -0.024 & 0.012 & -0.008 & -0.0056 & -0.012 & 0.08 & -0.077 & 0.016 & 0.043 & 0.051 & 0.046 & 0.09 & -0.34 \\
$\mathrm{Cr}$ & -0.12 & - & 0.0002 & -0.002 & - & - & -0.0043 & & 0.02 & - & -0.053 & -0.02 & -0.18 & -0.14 \\
$\mathrm{Ni}$ & 0.042 & -0.0003 & 0.0009 & - & - & - & 0.0057 & - & - & - & -0.0035 & -0.0037 & 0.013 & 0.0 \\
$\mathrm{Mo}$ & -0.1 & -0.0003 & - & - & - & - & - & - & - & - & - & -0.0005 & -0.10 & - \\
$\mathrm{W}$ & -0.15 & - & - & - & - & - & - & - & - & - & - & 0.035 & -0.07 & -0.052 \\
$\mathrm{Mn}$ & -0.07 & - & - & - & - & - & - & - & - & - & -0.0035 & -0.048 & -0.15 & -0.083 \\
$\mathrm{Si}$ & 0.18 & -0.0003 & 0.005 & - & - & - & 0.11 & 0.025 & 0.014 & 0.058 & 0.11 & 0.058 & 0.09 & -0.23 \\
$\mathrm{~V}$ & -0.34 & - & - & - & - & - & 0.42 & 0.015 & - & - & - & -0.028 & -0.35 & -0.97 \\
$\mathrm{Al}$ & 0.091 & - & - & - & - & - & 0.0056 & - & - & 0.045 & - & 0.03 & -0.058 & -6.6 \\
$\mathrm{P}$ & 0.13 & -0.03 & 0.0002 & - & - & - & 0.12 & - & 0.024 & - & 0.062 & 0.028 & 0.0002 & 0.13 \\
$\mathrm{~S}$ & 0.11 & -0.011 & - & 0.003 & 0.01 & -0.026 & 0.063 & -0.016 & -0.008 & 0.035 & 0.29 & -0.028 & 0.01 & -0.27 \\
$\mathrm{~N}$ & 0.103 & -0.046 & 0.0063 & -0.011 & -0.0015 & -0.04 & 0.047 & -0.093 & 0.009 & -0.03 & 0.045 & 0.007 & - & 0.05 \\
\hline
\end{tabular}




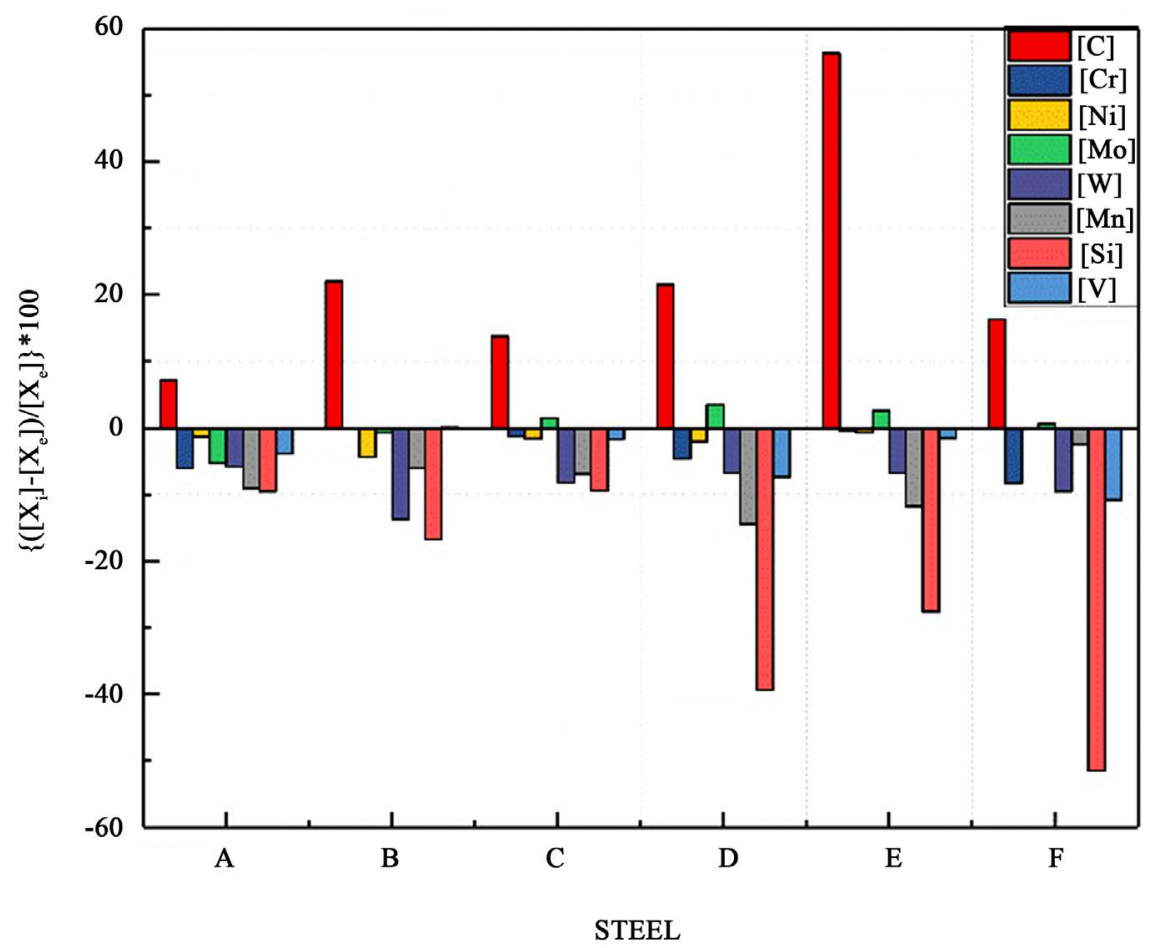

Figure 2. Percentage changes in elemental concentrations as a result of ESR. $[\mathrm{X}]=$ $[\mathrm{Cr}],[\mathrm{Ni}][\mathrm{Mo}],[\mathrm{W}],[\mathrm{Mn}],[\mathrm{Si}]$ and $[\mathrm{V}]$.

$$
\text { Net percentage change or loss }=\left(\left[x_{i}\right]-\left[x_{e}\right] /\left[x_{e}\right]\right) \times 100
$$

where $\left[x_{i}\right]=$ composition of the element in ingot

$\left[x_{e}\right]=$ composition of the elements in consumable electrode

As mentioned above, elemental losses increase with increasing affinity to oxygen through oxidation reactions. The free energy (non-standard state) changes per mole of $\mathrm{O}_{2}(\Delta \mathrm{G})$ of the following oxidation reactions at $1600^{\circ} \mathrm{C}$ is determined for the alloying elements which have some losses in this study, i.e. $\mathrm{Cr}, \mathrm{Ni}$, Mo, W, Mn, Si and V using the activity of each element and interactive Ellingham diagram [35].

$$
\begin{gathered}
4 / 3 \mathrm{Cr}+\mathrm{O}_{2} \rightarrow 2 / 3 \mathrm{Cr}_{2} \mathrm{O}_{3} \\
2 \mathrm{Ni}+\mathrm{O}_{2} \rightarrow 2 \mathrm{NiO} \\
\mathrm{Mo}+\mathrm{O}_{2} \rightarrow \mathrm{MoO}_{2} \\
\mathrm{~W}+\mathrm{O}_{2} \rightarrow \mathrm{WO}_{2} \\
2 \mathrm{Mn}+\mathrm{O}_{2} \rightarrow 2 \mathrm{MnO} \\
\mathrm{Si}+\mathrm{O}_{2} \rightarrow \mathrm{SiO}_{2} \\
4 / 3 \mathrm{~V}+\mathrm{O}_{2} \rightarrow 2 / 3 \mathrm{~V}_{2} \mathrm{O}_{3}
\end{gathered}
$$

Figure 3 illustrates the change, \% of alloying elements $\mathrm{Cr}, \mathrm{Ni}, \mathrm{Mo}, \mathrm{W}, \mathrm{Mn}, \mathrm{Si}$ and $\mathrm{V}$ in relation to the free energy of their oxidation reaction. It is clear that, while there is a tendency for the free energy of oxidation to affect the alloy losses during ESR, other factors are acting too. Account must also be taken of the reac- 


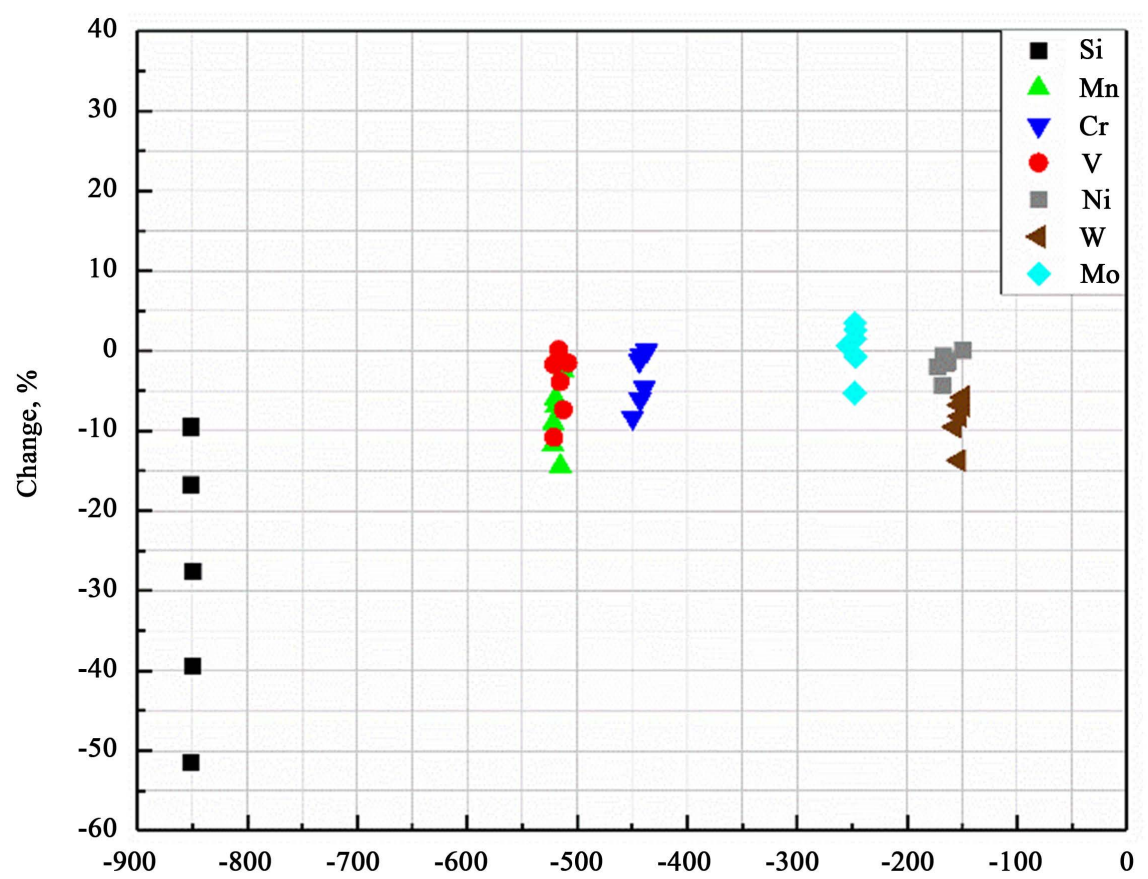

$\Delta \mathrm{G}, \mathrm{kJ} . / \mathrm{mole}$ of $\mathrm{O}_{2}$

Figure 3. Change, $\%$ of $\mathrm{Cr}, \mathrm{Ni}, \mathrm{Mo}, \mathrm{W}, \mathrm{Mn}, \mathrm{Si}$ and $\mathrm{V}$ as a function of the Gibbs free energy of oxidation per mol of $\mathrm{O}_{2}$ at $1600^{\circ} \mathrm{C}$ according to reactions (13 - 19).

tion kinetics between the slag and metal and the initial chemical composition of the electrode as well.

Since all the parameters of the ESR process such as the starting slag composition, melting rate, and power are fixed, the only variable is the initial chemical composition of the steel electrode. During ESR the molten steel contains many elements i.e. $\mathrm{Cr}, \mathrm{Ni}, \mathrm{Mo}, \mathrm{W}, \mathrm{Mn}, \mathrm{V}, \mathrm{Si}, \mathrm{C}, \mathrm{Al}, \mathrm{Cu}, \mathrm{S}, \mathrm{P}$ and $\mathrm{N}$, and the combined effect of all these elements must be considered. Therefore, the variation in the yield of the alloying elements was studied by considering the interaction parameters between all the elements in the molten state for the initial chemical composition. The activity coefficient of each alloying element was calculated using the WLE-formalism as shown in the following equation: [34]

$$
\log f_{i}=\sum_{j=2}^{k} e_{i}^{j}[\% j]
$$

where $i, j$ are the solute atoms in melt,

$f_{i}$ activity coefficient of solute atom $i$

$e_{i}^{j}$ interaction coefficient between solutes $i$ and $j$

$[\% j]$ concentration in $\%$ of solute atom $j$ in the melt

The activity of the elements in the molten steel $\left(a_{i}\right)$ is then given by the following expression:

$$
a_{i}=f_{i} \cdot x_{i}
$$

where $x_{i}$ is the mass content of the element $i$ in $\%$ in the steel. The interaction coefficients between all of the elements in the molten pool used to calculate the 
activity coefficient for each element in this study are given in Table 5. Activities and activity coefficients for all elements in the molten state are given in Table 6.

Figure 4 shows that increasing the activity of $\mathrm{Cr}, \mathrm{W}, \mathrm{V}, \mathrm{Mn}$ and $\mathrm{Ni}$ tends to decrease their yield in the final product. This is presumably because higher activity increases the tendency of these elements to be oxidized and taken into the slag thereby reducing the yield in the final product. The behavior of Mo differs from the other elements. In fact, the total percentage of Mo is increased in some cases as mentioned above due to the removal of the less stable elements such as $\mathrm{S}, \mathrm{N}, \mathrm{P}, \mathrm{Si}, \mathrm{Mn}, \mathrm{V}$ and Cr. It is difficult to draw conclusions about the effect of the activity of Mo since it is almost constant $(0.28-0.30)$ with only one alloy having a little higher activity at 0.44 .

The yield of $\mathrm{Ni}$ is very high and little affected by an increase in the Ni activity. Presumably, this can be attributed to the low affinity of $\mathrm{Ni}$ to $\mathrm{O}$.

The high affinity of $\mathrm{S}$ and $\mathrm{O}$ for $\mathrm{Mn}$ is seen in strong negative interaction coefficients and leads to a decrease the activity of $\mathrm{Mn}$ in the melt. The lower ac-
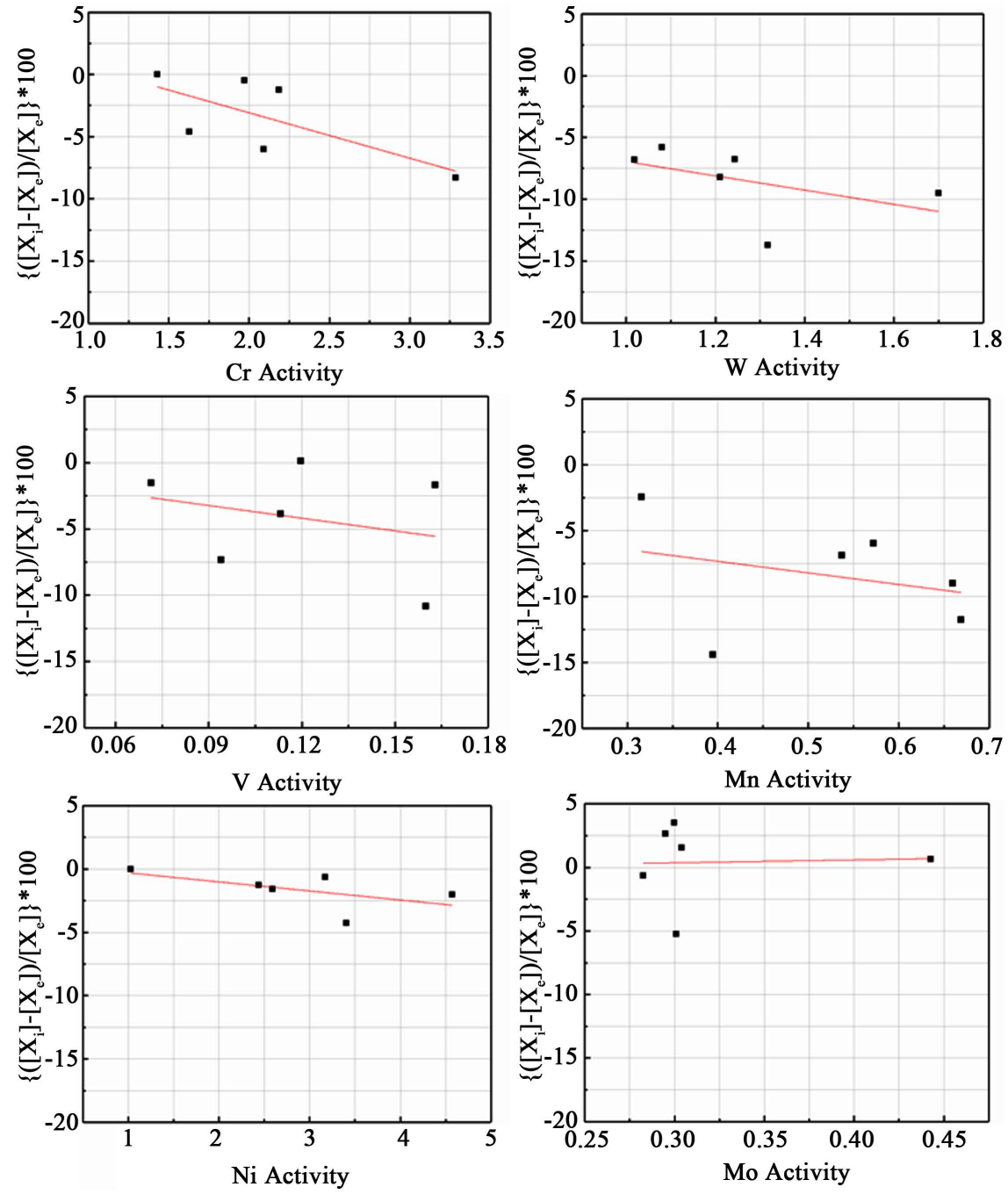

Figure 4. Effect of activity on the net change in [Cr], [W], [V], [Mn], [Ni] and [Mo]. 
Table 6. Activity coefficients $\left(f_{i}\right)$ and activities $\left(a_{i}\right)$ of constituents in the molten steel.

\begin{tabular}{|c|c|c|c|c|c|c|c|c|c|c|c|}
\hline Steel & $f_{i} \& a_{i}$ & $\mathrm{Cr}$ & $\mathrm{Ni}$ & Mo & W & $\mathrm{Mn}$ & $\mathrm{Si}$ & V & $\mathrm{P}$ & $S$ & $\mathrm{~N}$ \\
\hline \multirow{2}{*}{ A } & $f_{i}$ & 0.902 & 1.042 & 0.929 & 0.893 & 0.943 & 1.405 & 1.509 & 1.146 & 1.121 & 0.859 \\
\hline & $a_{i}$ & 2.092 & 2.439 & 0.301 & 1.080 & 0.659 & 0.996 & 0.113 & 0.031 & 0.027 & 0.011 \\
\hline \multirow{2}{*}{ B } & $f_{i}$ & 0.910 & 1.041 & 0.939 & 0.902 & 0.949 & 1.418 & 1.661 & 1.215 & 1.152 & 0.947 \\
\hline & $a_{i}$ & 1.429 & 3.405 & 0.283 & 1.317 & 0.572 & 1.109 & 0.120 & 0.033 & 0.022 & 0.019 \\
\hline \multirow{2}{*}{$\mathrm{C}$} & $f_{i}$ & 0.910 & 1.040 & 0.938 & 0.903 & 0.949 & 1.451 & 1.874 & 1.182 & 1.148 & 0.868 \\
\hline & $a_{i}$ & 2.185 & 2.591 & 0.304 & 1.210 & 0.537 & 1.296 & 0.163 & 0.031 & 0.029 & 0.017 \\
\hline \multirow{2}{*}{$\mathrm{D}$} & $f_{i}$ & 0.941 & 1.029 & 0.961 & 0.935 & 0.965 & 1.287 & 1.402 & 1.079 & 1.085 & 0.914 \\
\hline & $a_{i}$ & 1.628 & 4.571 & 0.300 & 1.243 & 0.395 & 0.658 & 0.094 & 0.026 & 0.024 & 0.020 \\
\hline \multirow{2}{*}{$\mathrm{E}$} & $f_{i}$ & 0.952 & 1.021 & 0.973 & 0.952 & 0.972 & 1.218 & 1.373 & 1.029 & 1.024 & 0.834 \\
\hline & $a_{i}$ & 1.971 & 3.174 & 0.295 & 1.019 & 0.669 & 0.576 & 0.071 & 0.025 & 0.019 & 0.017 \\
\hline \multirow{2}{*}{$\mathrm{F}$} & $f_{i}$ & 0.939 & 1.017 & 0.977 & 0.950 & 0.966 & 1.281 & 1.905 & 1.043 & 1.059 & 0.738 \\
\hline & $a_{i}$ & 3.287 & 1.028 & 0.443 & 1.700 & 0.316 & 1.122 & 0.160 & 0.031 & 0.024 & 0.024 \\
\hline
\end{tabular}

tivity of $\mathrm{Mn}$ in the melt and the higher activity of $\mathrm{MnO}$ according to Equation (21) in the slag lead to a pronounced reduction in the loss of manganese.

$$
(\mathrm{MnO})+[\mathrm{Fe}]=[\mathrm{Mn}]+(\mathrm{FeO})
$$

where $K=a_{[\mathrm{Mn}]} * a_{(\mathrm{FeO})} / a_{[\mathrm{Fe}]} * a_{(\mathrm{MnO})}$.

Mn has losses from $2 \%$ to $14 \%$ only through the six UHSS steel which is good agreement with the results of Bandyopadhyay et al. [36] who, using prefused slag of composition $70 \% \mathrm{CaF}_{2}-30 \% \mathrm{Al}_{2} \mathrm{O}_{3}$, $\mathrm{Ti}$ in the form of ferroalloy powder ( $\mathrm{FeTi}$ : $\mathrm{Ti} 35 \%, \mathrm{Al} 5 \%$ ) used as inoculants, high carbon ferrochrome powder used to compensate the losses of $\mathrm{C}$ and $\mathrm{Cr}$, and continuous addition of $\mathrm{Al}$ during ESR, concluded that the losses of manganese during ESR was in the range $2 \%-13 \%$.

The high affinity of Si for O leads to a lower yield. FeO formed in the slag as a result of oxygen diffusion from the atmosphere leads to the oxidation of $\mathrm{Si}$ in the consumable electrode according to the reaction:

$$
[\mathrm{Si}]+2(\mathrm{FeO}) \leftrightarrow 2[\mathrm{Fe}]+\left(\mathrm{SiO}_{2}\right)
$$

Also by increasing $\mathrm{Al}_{2} \mathrm{O}_{3}$ in the slag to high level, Si start to reduce $\mathrm{Al}_{2} \mathrm{O}_{3}$ and it oxidized to $\mathrm{SiO}_{2}$ and transferred to the slag which increase the losses of $\mathrm{Si}$ as illustrate by the following reaction:

$$
3[\mathrm{Si}]_{\text {metal }}+2\left(\mathrm{Al}_{2} \mathrm{O}_{3}\right)_{\text {slag }}=4[\mathrm{Al}]_{\text {metal }}+3\left(\mathrm{SiO}_{2}\right)_{\text {slag }}
$$

Subsequently, $\mathrm{SiO}_{2}$ reacts with $\mathrm{CaO}$ to form very stable calcium silicate in the slag which decreases the silica activity and the yield of Si in the alloy. As shown in Figure 2, Si losses during ESR varied from $9 \%$ to $51 \%$ in the six UHSS. This result is in agreement with the observation of Bandyopadhyay et al. [36], who concluded that the losses of silicon content during ESR was found to be in the range $0 \%-55 \%$, and the results of Burak et.al. [33], who using various synthetic slag compositions which composed mainly of $\mathrm{CaF}_{2}-\mathrm{Al}_{2} \mathrm{O}_{3}-\mathrm{CaO}$ ternary systems 
with traces of $\mathrm{FeO}, \mathrm{MnO}, \mathrm{SiO}_{2}$ and $\mathrm{MgO}$, reported that the losses of Si up to $60 \%$ in ESR.

In the case of Si, there seems to be a tendency for the losses to decrease somewhat as the activity of Si increases, see Figure 5. This may be due to the lower percent of oxygen resulting from addition of $\mathrm{Al}$ as by increasing the $\mathrm{Al}$ pick up in the produced ingot the losses of oxygen are increased while the losses of $\mathrm{Si}$ are decreased which clearly illustrated in Figure 6.

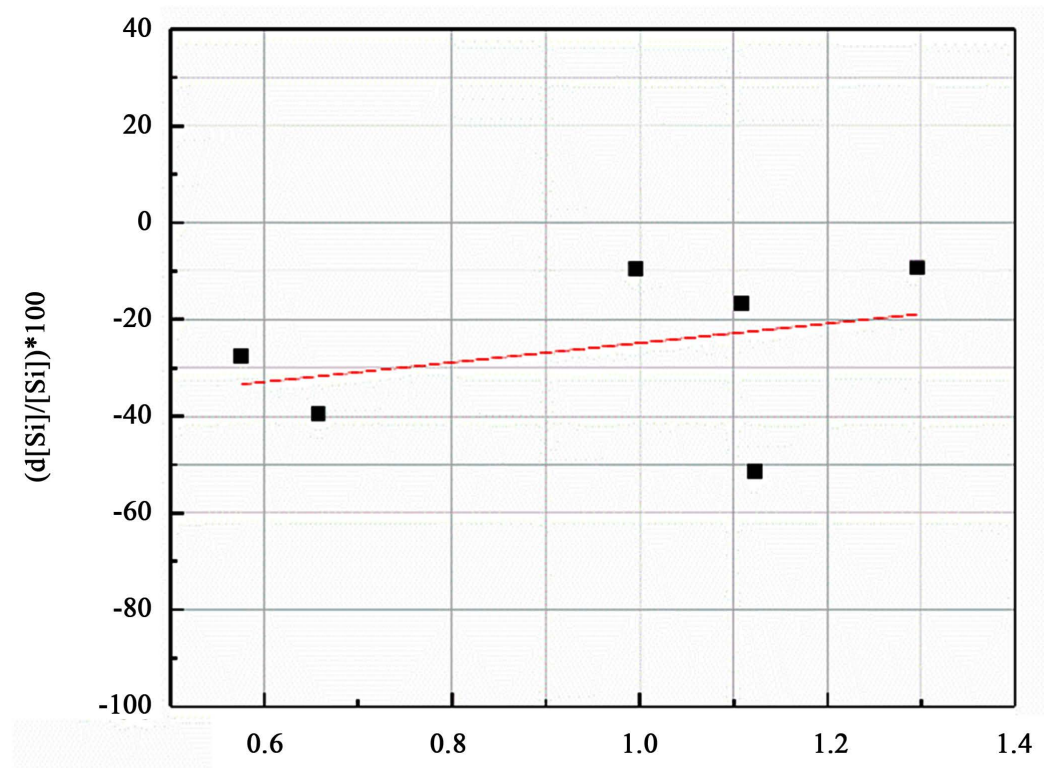

Si Activity

Figure 5. Effect of activity on the net change in [Si].

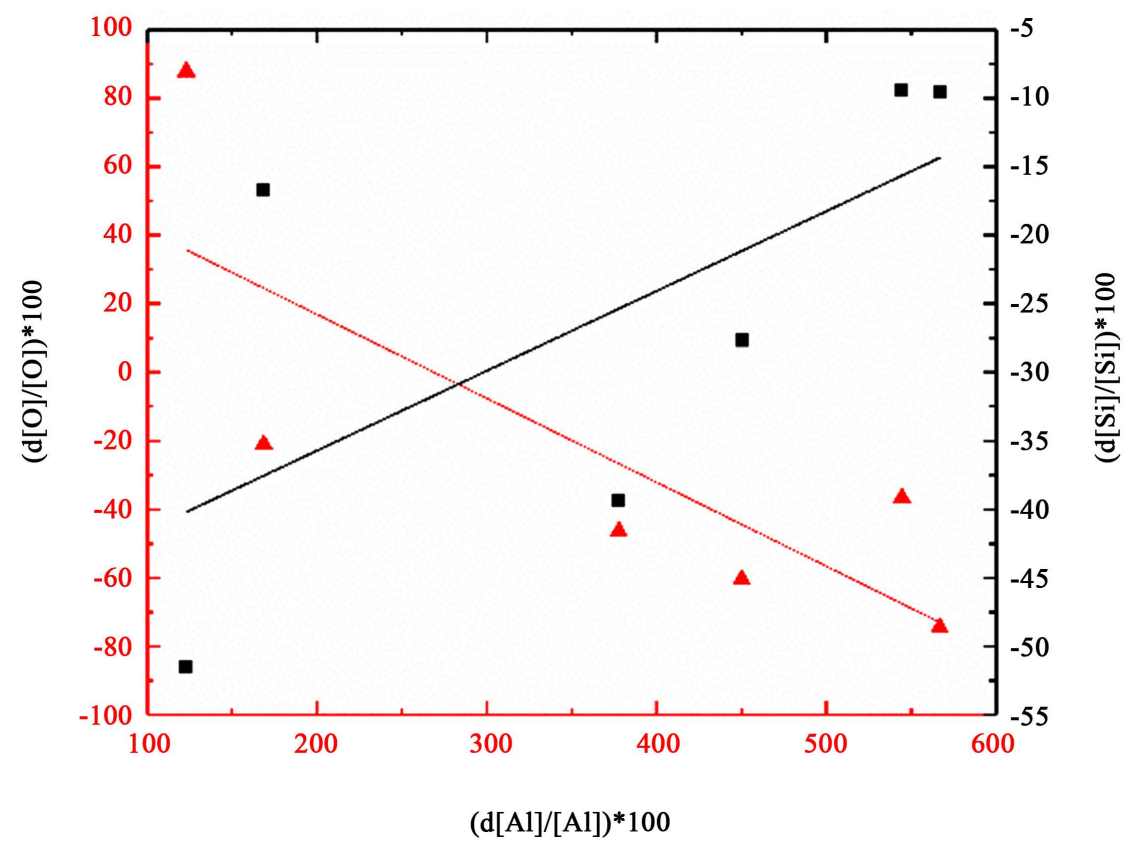

Figure 6. Effect of $\mathrm{Al}$ change, \% on the change, \% of $\mathrm{O}$ and $\mathrm{Si}$. 
There is an increase in the $\mathrm{Al}$ content of all steel ingots in the range $(0.016 \%$ $0.051 \%$, see Table 4 ) due to the addition of $\mathrm{Al}$ as a deoxidant during ESR. The mechanism of $\mathrm{Al}$ pick up is not clear. As $\mathrm{Al}$ is added to reduce the $\mathrm{FeO}$ content in the slag. Any excess Al will form a layer floating on the slag surface as the density of molten $\mathrm{Al}$ is lower than the density of the slag. This layer will be oxidized to $\mathrm{Al}_{2} \mathrm{O}_{3}$ which implies that it is difficult for the $\mathrm{Al}$ added to directly enter the metal. However, the presence of elements like Si may reduce some alumina at the slag/metal interface lead to an increase of the $\mathrm{Al}$ content in the produced ingot as shown in Figure 7 and according to the reaction in Equation (23). The high scattering shown in Figure 7 and the lower value of $\mathrm{Al}$ content at Si activity 1.12 and 1.11 , may be results from increasing the $\mathrm{Al} \%$ and its activity in the slag which leads reaction (23) goes backward.

The pre-fusion process increases the carbon content of the slag partly due to the layer of carbon paste on the furnace wall and bottom and partly due to the graphite electrode used in the submerged electric arc furnace. This leads to a slight increment of $\mathrm{C}$ content of the steel ingots and a corresponding decrease in the carbon content of the slag during ESR as can be seen in Table 7.

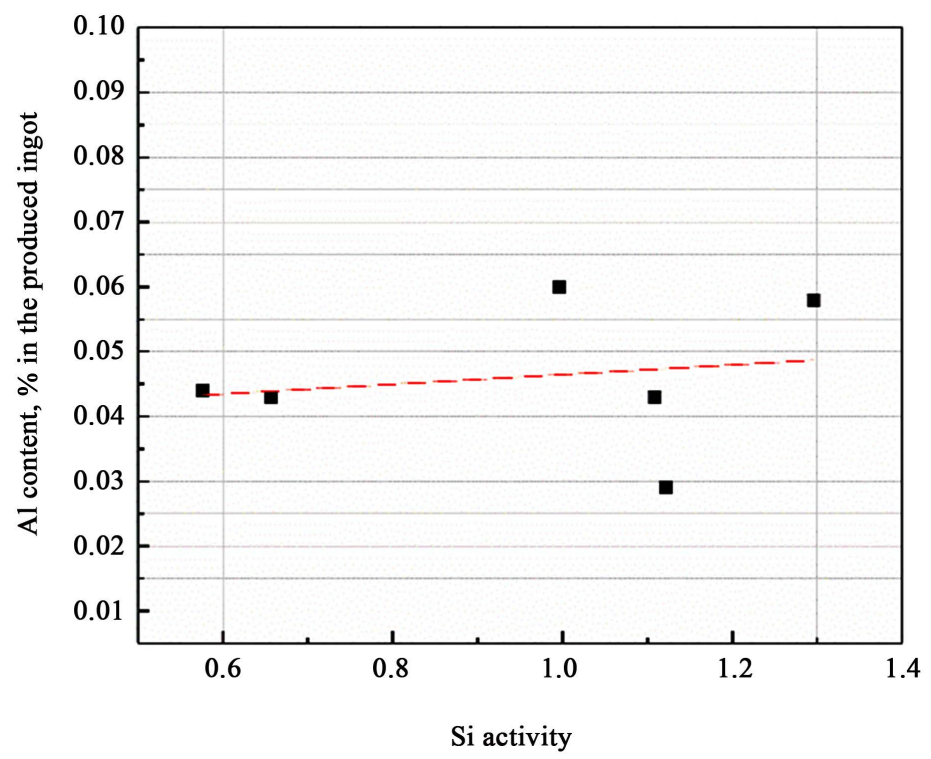

Figure 7. Effect of Si activity on the $\mathrm{Al}$ content, \% in the produced ingot.

Table 7. Carbon content in slag before and after ESR.

\begin{tabular}{ccc}
\hline Slag & C\% in fused slag & C\% in slag after ESR \\
\hline A & & 0.012 \\
B & & 0.021 \\
C & 0.026 & 0.0012 \\
D & & 0.0013 \\
E & 0.025 \\
F & 0.0011
\end{tabular}




\subsection{Effect of ESR Process on the P, $S$ and $N$ Contents}

Desulphurization depends on the activity of sulphur in the steel consumable electrode. As shown in Figure 8, ESR with the 70:15:15 slag has a good desulphurizing power (from $21 \%$ - 46\%) for all the UHSS studied. These results are in agreement with those of Bandyopadhyay et al. [36], who concluded that there is a decrease in the concentration of sulphur in the metal during ESR reaching up to $30 \%-50 \%$.

The difference in the degree of desulphurization between the different steels may be the result of the variations in the primary chemical compositions of the steels. Based on the interaction coefficient between elements in ternary iron based alloys there are different elements with a positive interaction coefficient viz., Si, Mo, W, $\mathrm{Al}$ and $\mathrm{C}$ which lead to decrease the activity of $\mathrm{S}$ to move from metal to slag. On the other hand, $\mathrm{Al}$ and $\mathrm{Si}$ have high affinity to $\mathrm{O}$, which decreases the oxygen partial pressure in the molten metal and leads to enhancement in the activity of $\mathrm{S}$ to react with cations forming element like $\mathrm{Mn}^{+}, \mathrm{Ca}^{+}$, etc. These carry $\mathrm{S}$ from the molten metal droplet to the slag as CaS, MnS, etc. By increasing the activity of $S$ in the molten steel pool, the desulphurization process is enhanced as shown in Figure 9.

Also, the activity of sulphur is based on the activity of oxygen as increasing the activity of oxygen in the molten steel leads to a decrease in the activity of sulphur and consequently decreases the desulphurization degree. This can be illustrated by the following:

$$
\mathrm{S}_{\text {metal }}+\mathrm{O}_{\text {slag }}^{2-} \leftrightarrow O_{\text {metal }}+\mathrm{S}_{\text {slag }}^{2-}
$$

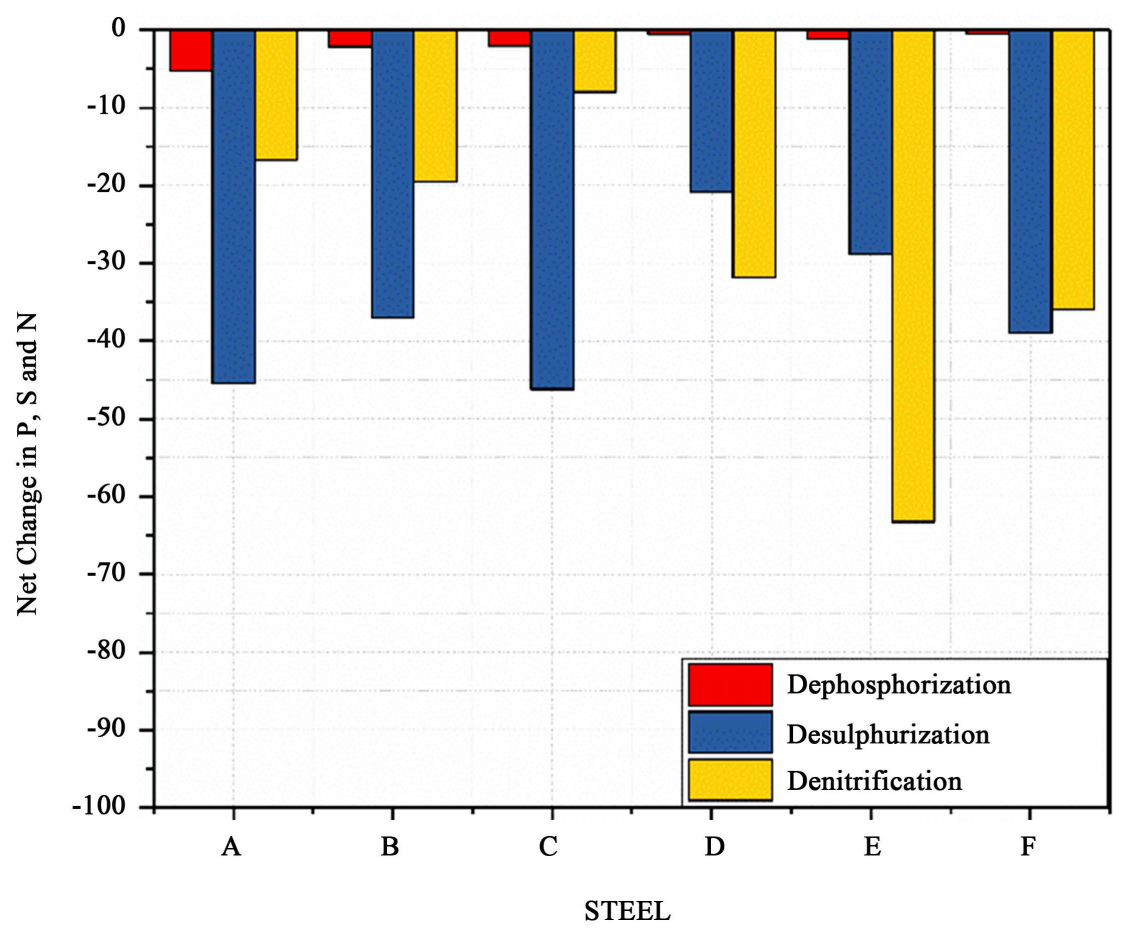

Figure 8. Net change, \% in X: S, P and N caused by ESR. 


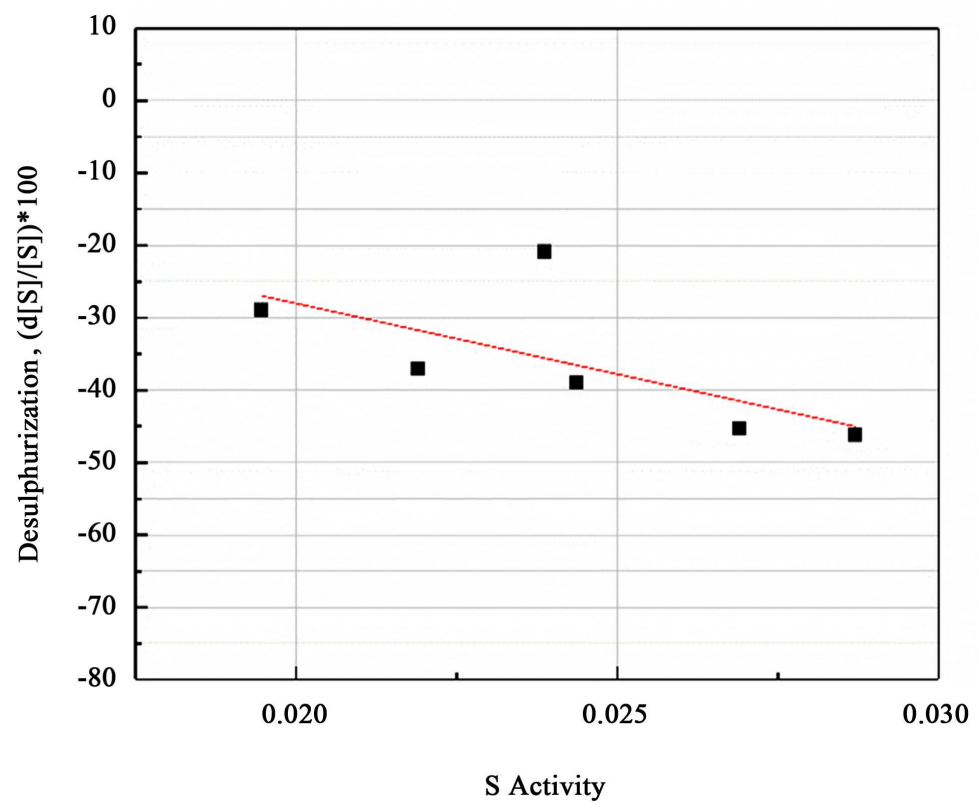

Figure 9. Effect of activity of $S$ on the desulphurization process.

To determine the mechanism of the desulphurization process, the $\mathrm{S}$ contents of the different steels and their related slags after the electroslag refining process were determined and used to calculate the percentages of $S$ removed to the slag and to the atmosphere. The results are shown in Table 8. It was observed that the main mechanism for the desulphurization process, accounting for about $97 \%$ - $99 \%$ of the sulphur removal, was removed as gas by metal-gas and slag-gas interactions. These results are in good agreement with those of Mattar et al. [8] who concluded that about $80 \%$ of sulphur removal is occurs by metal-gas and slag-gas reactions.

Dephosphorization Process In the steels under investigation, $\mathrm{P}$ removal was limited to 5\%, slightly decreasing as the $\mathrm{P}$ activity increased, as shown in Figure 10. Thus, there is an inappreciable effect of ESR on the dephosphorization process. The removal of $\mathrm{P}$ from steel is based on the relatively high partial pressure and activity of oxygen to form phosphorus pentoxide which can then be transferred to the slag, but this condition cannot be achieved in the present case, so there is little effect of ESR on the removal of P from the investigated steels.

Denitrification process Many parameters influence the nitrogen content in steel ingot produced from ESR process, but the most important parameters are the chemical compositions of the slag and the consumable electrode. To help understand the denitrification phenomenon the nitrogen distribution between the metal and the slag were determined before and after ESR, see Table 4 and Table 9.

The removal of nitrogen from the steels ranged from $8 \%$ to $63 \%$, which shows that denitrification can be obtained during ESR, see also Figure 8. These results agreed with the results obtained by Eissa et al. [37] who studied nitrogen behavior during ESR of titanium free tool steels and concluded that about $15 \%$ to 


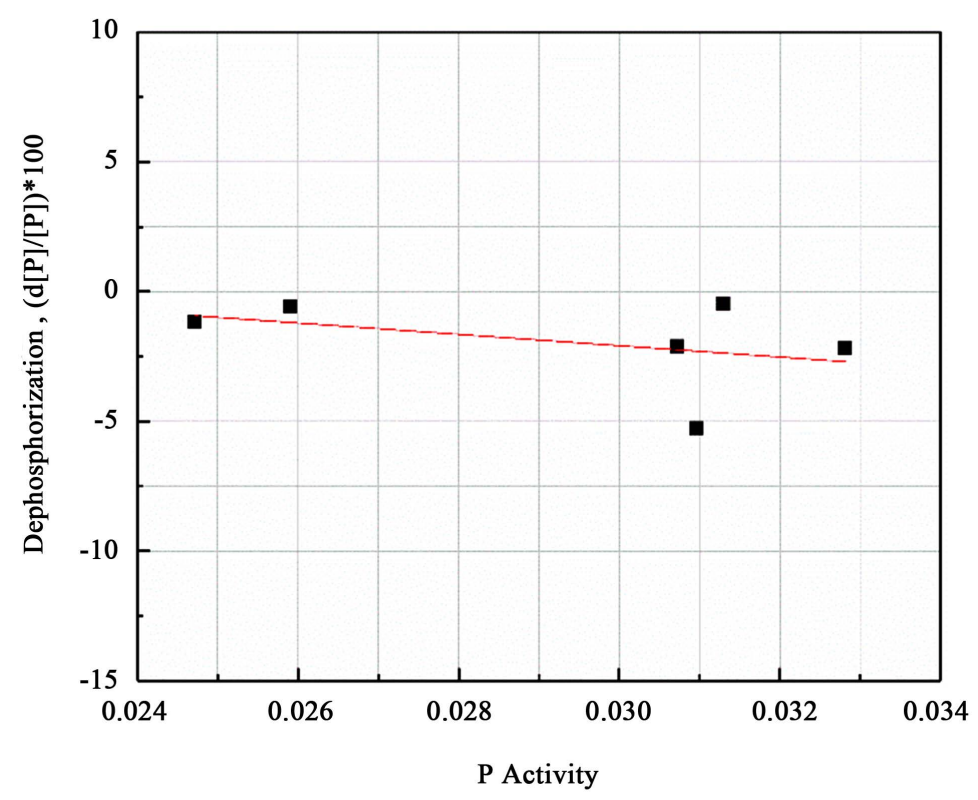

Figure 10. Effect of activity of $\mathrm{P}$ on the dephosphorization process.

Table 8. Removal of S from steel to slag and air.

\begin{tabular}{ccc}
\hline \multirow{2}{*}{ Steel No. } & \multicolumn{2}{c}{ Wt\% of S removal from steel } \\
\cline { 2 - 3 } & To slag & To air \\
\hline A & 3.04 & 96.96 \\
B & 2.86 & 97.14 \\
C & 2.20 & 97.80 \\
D & 1.86 & 98.76 \\
E & 3.75 & 96.25 \\
F & 1.32 & 98.68 \\
\hline
\end{tabular}

Table 9. Nitrogen content in slag before and after ESR.

\begin{tabular}{ccccccc}
\hline & A & B & C & D & E & F \\
\hline N\% in fused slag & & \multicolumn{7}{c}{0.017} \\
N\% in slag after ESR & 0.034 & 0.043 & 0.040 & 0.057 & 0.071 & 0.053 \\
\hline
\end{tabular}

$67 \%$ of the initial electrode nitrogen content can be removed by ESR. $A$. Ahmed et al. [38] investigated nitrogen removal from AISI M41 tool steel using different slag systems containing the following percentages of $\mathrm{CaF}_{2}, \mathrm{CaO}$ and $\mathrm{Al}_{2} \mathrm{O}_{3}$ : 65-15-20, 75-15-10, and 55-30-15. The reductions in $\mathrm{N}$ content were respectively $82 \%, 20 \%$, and $31 \%$ which are at a similar level to those observed here.

The denitrification effect of the slag may be due to the presence of $\mathrm{CaO}$ which depolymerizes the $\mathrm{Al}_{2} \mathrm{O}_{3}$ network and increases the concentration of free oxygen ions $\left(\mathrm{O}^{2-}\right)$ and non-bridging oxygen ions $\left(\mathrm{O}^{-}\right)$. This leads to an increase in nitrogen transfer to the slag in the form of free nitrides $\left(\mathrm{N}^{3-}\right)$ according to Equation (5) and (7) and also as non-bridging nitrides $\left(\mathrm{N}^{-}\right)$according to Equation 
(6). [27] The presence of $\mathrm{CaF}_{2}$ also assists in the depolymerization effect and this leads to an increase in the nitrogen solubility in the slag because fluorine has the ability to liberate both oxygen ions and incorporated nitrides from the $\mathrm{Al}_{2} \mathrm{O}_{3}$ network [26] [30] [38] [39] [40] [41].

Many factors influence the removal of nitrogen such as slag viscosity; removal of nitride inclusions by physical removal, dissociation and flotation, or the reaction with the slag phases or carbon according to Equations (7) and (8). The presence of traces of $\mathrm{TiO}_{2}$ can raise the solubility of $\mathrm{N}$ in the slag where the nitrogen will incorporate into titanate networks. The increasing content of $\mathrm{Al}_{2} \mathrm{O}_{3}$ in the slag during the process leads to an increase in the slag viscosity and removal of N. However, all of these parameters are fixed or the same in this study because they are related to the single slag that was used in this study. However, we still see variations in the degree of denitrification obtained with different electrode compositions so the chemical composition of the steel is also an important factor. Chen [30] also concluded that alloying elements and impurities contained in the steel affect the denitrification process.

There are different elements have different effect of the solubility of the nitrogen in molten steel. $\mathrm{C}, \mathrm{Ni}, \mathrm{Si}, \mathrm{Al}, \mathrm{Cu}$ and $\mathrm{O}$ have negative effect on the solubility of nitrogen while $\mathrm{Cr}, \mathrm{Mo}, \mathrm{V}, \mathrm{Mn}$ and $\mathrm{W}$ have a positive effect on the solubility of nitrogen which leads to decrease the denitrification process. The principle factors in controlling the absorption site fraction in liquid alloys are the content of impurities sulphur and oxygen respectively. Both of which are more strongly surface active than nitrogen. It is assumed that these elements change the energetics of nitrogen adsorption by increasing the activity of vacant sites at metal surface [40].

Figure 11 shows that the degree of denitrification in the current study increases with increasing $\mathrm{N}$ activity in the molten metal.

Based on the nitrogen content of steel and slag before and after ESR, the sources of $\mathrm{N}$ in the slag can be calculated as shown in Table 10. These results show that a lower solubility of atmospheric $\mathrm{N}$ in the slag provides a higher protection for the molten steel against $\mathrm{N}$ pick-up.

Figure 12 illustrates the presence of a strong correlation between denitrification and $\mathrm{S}$ activity of the investigated steels. This can be understood on the basis

Table 10. Increase in nitrogen content of the slag caused by removal from the steel and reaction with the air.

\begin{tabular}{ccc}
\hline \multirow{2}{*}{ Steel No. } & \multicolumn{2}{c}{ Wt\% of N increment } \\
\cline { 2 - 3 } & From Steel & From air \\
\hline A & 77.50 & 22.50 \\
B & 68.67 & 31.33 \\
C & 54.95 & 45.05 \\
D & 85.71 & 13.94 \\
E & 90.19 & 9.81 \\
F & 98.32 & 1.68
\end{tabular}




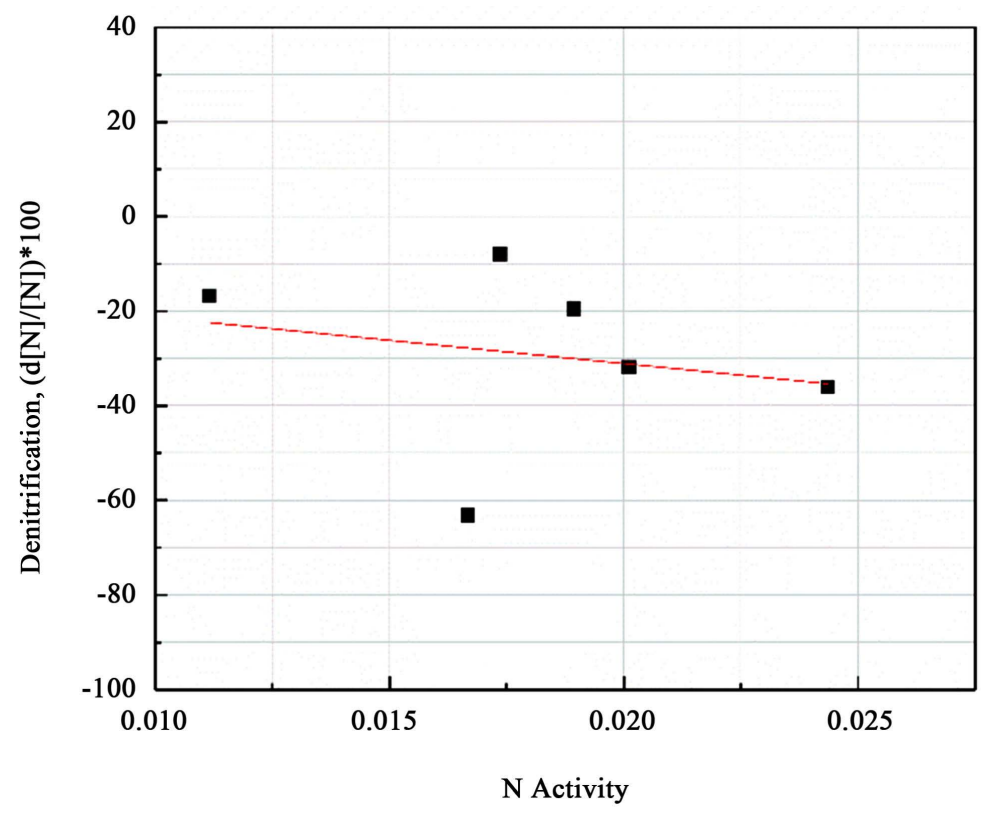

Figure 11. Effect of activity of $\mathrm{N}$ on the denitrification, \% process.

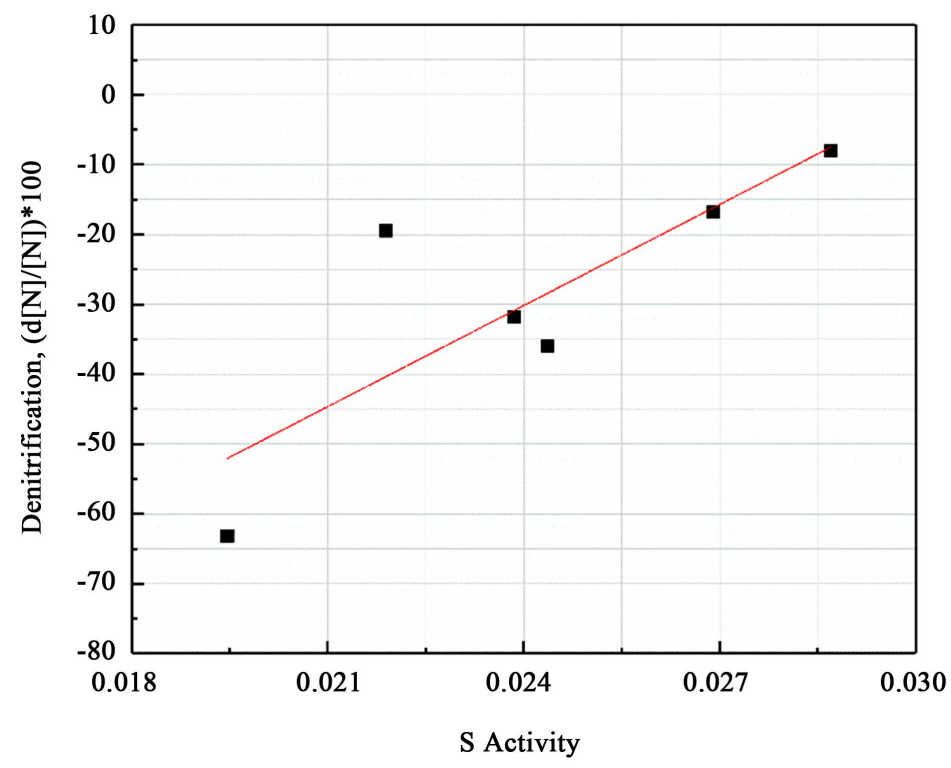

Figure 12. Relationship between $\mathrm{S}$ activity and denitrification process.

of the effect of $\mathrm{S}$ on the kinetics of denitrification through its tendency to segregate to surfaces.

\section{Conclusions}

The effects of the activities of the alloying elements $\mathrm{C}, \mathrm{Cr}, \mathrm{Ni}, \mathrm{Mo}, \mathrm{W}, \mathrm{Mn}$ and $\mathrm{V}$ and the impurities $\mathrm{S}, \mathrm{P}, \mathrm{N}$ and $\mathrm{O}$ on the yield of alloying elements and the degree of purification caused by electroslag remelting with a prefused $\mathrm{CaF}_{2}$ based slag has been studied for six potential ultrahigh-strength steel compositions. They were melted in an induction furnace, refined using ESR together with a slag 
comprising $70 \% \mathrm{CaF}_{2}, 15 \% \mathrm{CaO} 15 \% \mathrm{Al}_{2} \mathrm{O}_{3}$, and then hot forged before final chemical analysis. The results showed the following.

1) Overall, the synthetic slag used in the refining process gave a high yield of the alloying elements apart from Si.

2) The yield of alloying elements not only depends on the slag composition and ESR parameters, but also on the starting chemical composition of the consumable electrode, or rather, the activities of the alloying elements as determined by the interaction coefficients between the elements.

3) Increasing the activity of the $\mathrm{Cr}, \mathrm{W}, \mathrm{V}, \mathrm{Mn}$ and $\mathrm{Ni}$ led to a decrease in their yield in the final product.

4) The yield of Mo was even increased in some cases, due to its extremely low interaction coefficient with oxygen and its less negative free energy of oxidation combined with the fact that the impurities $\mathrm{S}, \mathrm{N}$ and $\mathrm{P}$ and other alloying elements like $\mathrm{Si}, \mathrm{Mn}, \mathrm{V}$ and $\mathrm{Cr}$ are removed.

5) Due to the low interaction coefficient of $\mathrm{Ni}$ with $\mathrm{O}$ the yield of $\mathrm{Ni}$ is high in all the investigated steels.

6) The relatively high yield of manganese despite the strong negative interaction with $\mathrm{O}$ and $\mathrm{S}$ can be explained by the high activity coefficient of $\mathrm{MnO}(\mathrm{MnO})$ in the slag.

7) There is a high loss of silicon due to its highly negative free energy of oxidation. Also, when $\mathrm{Si}$ in the consumable electrode is oxidized to $\mathrm{SiO}_{2}$ in the slag, reaction with $\mathrm{CaO}$ to form a stable calcium silicate lowers the activity of $\mathrm{SiO}_{2}$, which further reduces the concentration of $\mathrm{Si}$ in the final ingots.

8) Increasing the activity of $S$ in the molten steel pool enhances the degree of desulphurization. About $97 \%$ - 99\% of the sulphur removed from the steel is removed as gas by metal-gas and slag-gas interactions. Also by ESR causes no pronounced dephosphorization.

9) Denitrification can be performed using ESR with 70-15-15 $\mathrm{CaF}_{2}-\mathrm{CaO}-\mathrm{Al}_{2} \mathrm{O}_{3}$ synthetic slag. The degree of denitrification depends not only on the slag properties but also on the chemical composition of the consumable electrode.

10) This study shows that not only the chemical composition of the slag but also the activity of the elements in the molten metal must be taken into account in any further studies related to the production of high quality steel using ESR or pressure electroslag remelting (PESR).

\section{Acknowledgements}

The authors acknowledge the Egyptian Ministry of Higher Education (Cultural Affairs and Missions Sector) for the financial support during this work and Dr. Eetu-Pekka Heikkinen and Mr. Ville-Valtteri Visuri from the Process Metallurgy Research Unit at the University of Oulu, Finland for valuable discussions.

\section{References}

[1] Philip, T.V. and Mccaffrey, T.J. (1990) Ultrahigh-Strength Steels. ASM International, Metals Handbook, 10th Edition, Vol. 1, 430-448. 
[2] Maity, S.K. and Kawalla, R. (2011) Ultrahigh-Strength Steel: Development of Mechanical Properties through Controlled Cooling. In: Heat Transfer-Engineering Applications.

[3] Kömi, J., Karjalainen, P. and Porter, D. (2016) Direct-Quenched Structural Steels. In: Encyclopedia of Iron, Steel, and Their Alloys, 1109-1125. https://doi.org/10.1081/E-EISA-120049737

[4] Vaish, A.K., Iyer, G.V.R., De, P.K., Lakra, B.A., Chakrabarti, A.K. and Ramachandrarao, P. (2000) Electroslag Remelting-Its Status, Mechanism and Refining Aspects in the Production of Quality Steels. Journal of Metallurgy and Materials Science, 42, 11-29.

[5] Duckworth, W.E. and Hoyle, G. (1969) Electro-Slag Refining. Chapman and Hall, London.

[6] Scholz, U.B.H. (1995) Electroslag Remelting Technologies in the Past and Future. MPT International, 31, 36-43.

[7] Mattar, T., El-Fawakhry, K., Halfa, H. and Eissa, M. (2008) Effect of Nitrogen Alloying on Sulphur Behaviour during ESR of AISI M41 Steel. Steel Research International, 79, 691-697. https://doi.org/10.1002/srin.200806185

[8] Mattar, T. (2009) Effect of ESR and Nitrogen Alloying on the Cleanliness of M41 Steel. Journal of Materials Sciences and Technology, 17, 35-46.

[9] Mattar, T.M.T, Fathy, A.M., El-Faramawy, H.S.R., Eissa, M.M. and El-Fawakhry, K.A.R. (2001) Optimization of Desulphurization of Tool Steels during EAF and ESR Processes. Metal 2001, Ostrava, 1-6.

[10] Mehrabi, K., Rahimipour, M.R. and Shokuhfar, A. (2005) The Effect of Slag Types and Melting Rate on Electro-Slag Remelting (ESR) Processing. International Journal of Iron \& Steel Society of Iran, 2, 37-42.

[11] Hayashi, M., Sano, N. and Fredriksson, P. (2004) Evaluation of Thermodynamic Activity of a Metallic Oxide in a Ternary Slag from the Sulphide Capacity of the Slag. ISIJ International, 44, 1783-1786. https://doi.org/10.2355/isijinternational.44.1783

[12] Eissa, M. and EI-Mohammadi, A. (1998) Effect of Physical Properties of Slag on Sulphur Removal Mechanism during ESR Process. Steel Research International, 69, 413-417. https://doi.org/10.1002/srin.199805573

[13] Yang, Y., McKague, A.R., Sommerville, I.D. and McLean, A. (1997) Phosphate and Sulphide Capacities of $\mathrm{CaO}-\mathrm{CaCl} 2-\mathrm{CaF} 2$ Slags. Canadian Metallurgical Quarterly, 36, 347-354.

[14] Nasu, M., Mills, K.C., Monaghan, B.J., Jakobsson, A. and Seetharaman, S. (1999) Effect of Slag/Metal Interfacial Tension on Kinetics of Dephosphorisation. Ironmaking \& Steelmaking, 26, 353-357. https://doi.org/10.1179/030192399677211

[15] Kawai, Y., Nakao, R. and Mori, K. (1984) Dephosphorization of Liquid Iron by CaF2-Base Fluxes. Transactions of the Iron and Steel Institute of Japan, 24, 509-514. https://doi.org/10.2355/isijinternational1966.24.509

[16] Hoyle, G. (1983) Electroslag Processes, Principles and Practice. Applied Science Publishers, London/New York.

[17] Werner, E. (1988) Solid Solution and Grain Size Hardening of Nitrogen-Alloyed Austenitic Steels. Materials Science and Engineering: A, 101, 93-98. https://doi.org/10.1016/0921-5093(88)90054-8

[18] Di Schino, A. and Kenny, J.M. (2003) Grain Refinement Strengthening of a Micro-Crystalline High Nitrogen Austenitic Stainless Steel. Materials Letters, 57, 
1830-1834. https://doi.org/10.1016/S0167-577X(02)01076-5

[19] Gavriljuk, V.G., Berns, H., Escher, C., Glavatskaya, N.I., Sozinov, A. and Petrov, Y.N. (1999) Grain Boundary Strengthening in Austenitic Nitrogen Steels. Materials Science and Engineering: A, 271, 14-21. https://doi.org/10.1016/S0921-5093(99)00272-5

[20] Speidel, M.O. (2005) New Nitrogen-Bearing Austenitic Stainless Steels with High Strength and Ductility. Metal Science and Heat Treatment, 47, 489-493. https://doi.org/10.1007/s11041-006-0017-y

[21] Ikegami, Y. and Nemoto, R. (1996) Effect of Thermo-Mechanical Treatment on Mechanical Properties of High-Nitrogen Containing Cr-Mn-Ni Austenitic Stainless Steels. ISIJ International, 36, 855-861. https://doi.org/10.2355/isijinternational.36.855

[22] Fréchard, S., Redjaimia, A., Lach, E. and Lichtenberger, A. (2006) Mechanical Behaviour of Nitrogen-Alloyed Austenitic Stainless Steel Hardened by Warm Rolling. Materials Science and Engineering: A, 415, 219-224. https://doi.org/10.1016/j.msea.2005.09.070

[23] Ito, K. and Fruehan, R.J. (1988) Thermodynamics of Nitrogen in $\mathrm{CaO}-\mathrm{SiO}_{2}-\mathrm{AI}_{2} \mathrm{O}_{3}$ Slags and Its Reaction with Fe-C Sat Melts. Metallurgical Transactions B, 19, 419-425. https://doi.org/10.1007/BF02657739

[24] Min, D.J. and Fruehan, R.J. (1990) Nitrogen Solution in $\mathrm{BaO}-\mathrm{B}_{2} \mathrm{O}_{3}$ and $\mathrm{CaO}-\mathrm{B}_{2} \mathrm{O}_{3}$ Slags. Metallurgical Transactions B, 21, 1025-1032.

https://doi.org/10.1007/BF02670273

[25] Mulfinger, H.O. (1966) Physical and Chemical Solubility of Nitrogen in Glass Melts. Journal of the American Ceramic Society, 49, 462-467. https://doi.org/10.1111/j.1151-2916.1966.tb13300.x

[26] Sohn, I., Min, D.J. and Park, J.H. (1999) Thermodynamic Study on the Effect of $\mathrm{CaF}_{2}$ on the Nitrogen and Carbon Solubility in the $\mathrm{CaO}-\mathrm{Al}_{2} \mathrm{O}_{3}-\mathrm{CaF}_{2}$ Slag System. Steel Research International, 70, 215-220. https://doi.org/10.1002/srin.199905629

[27] Eloy, M.R. and Sano, N. (1990) Nitrogen Solubility in $\mathrm{CaO}-\mathrm{SiO}_{2}, \mathrm{CaO}-\mathrm{MgO}-\mathrm{SiO}_{2}$, and $\mathrm{BaO}-\mathrm{MgO}-\mathrm{SiO}_{2}$ Melts. Metallurgical and Materials Transactions B, 21, 97-104. https://doi.org/10.1007/BF02658120

[28] Nafziger, R.H. (1976) Electroslag Melting Process (No. PB-263219; BM-B-669) Bureau of Mines. Albany Metallurgy Research Center, Albany.

[29] Mattar, T. (2002) Electro-Slag Remelting of AISI M41 High-Speed Tool Steel Scrap. 6th International Tooling Conference, Karlstad, 10-13.

[30] Chen, J.X. (1990) Iron and Steel Metallurgy: Steelmaking Part. Metallurgical Industry Press, Beijing, 90. (In Chinese)

[31] Halfa, H. (2003) Improvement of High-Speed Tool Steel by Using Electro-Slag Remelting Technology. M.Sc. Thesis, Faculty of Engineering, Cairo University, Egypt.

[32] Reitz, J., Maurischat, M., Friedrich, B. and Recycling, M. (2008) Optimized Control of Slag Chemistry for the Electroslag Remelting of Large Size Ingots. 17 th International Forge Masters Meeting, 3-7.

[33] Birol, B. and Saridede, M.N. (2016) The Effect of Slag Optical Basicity on Alloying Element Losses of Steel by Electroslag Remelting (ESR). Transactions of the Indian Institute of Metals, 69, 751-757. https://doi.org/10.1007/s12666-015-0549-1

[34] Engh, T. (1992) Principles of Metal Refining. Oxford University Press, Oxford, 473.

[35] https://www.doitpoms.ac.uk/tlplib/ellingham_diagrams/interactive.php

[36] Bandyopadhyay, T.R., Rao, P.K. and Prabhu, N. (2012) Behavior of Alloying Ele- 
ments during Electro-Slag Remelting of Ultrahigh-Strength Steel. Metallurgical \& Mining Industry, 4.

[37] Eissa, M., Mattar, T. and El-Fawakhry, K. (1999) Proceedings of the 5th International Conference on Tooling "Tool Steels in the Next Century". University of Leoben, Austria, 275.

[38] Ahmed, A. and Fathy, A. (2008) Effect of Slag Properties and Nitrogen Addition on Behaviour of Alloying Elements during ESR of AISI M41 Tool Steel. Ironmaking \& Steelmaking, 35, 458-464. https://doi.org/10.1179/174328108X318356

[39] Pehlke, R.D. and Elliott, J.F. (1960) Solubility of Nitrogen in Liquid Iron Alloys. 1. Thermodynamics. Transactions of the American Institute of Mining and Metallurgical Engineers, 218, 1088-1101.

[40] Hajra, J.P. and Divakar, M. (1999) Thermodynamics of Surfaces and Adsorption in the Fe-S, Fe-N, and Fe-SN Systems at 1823 K. Metallurgical and Materials Transactions B, 30, 429-433. https://doi.org/10.1007/s11663-999-0075-9

[41] Martinez, E.R., Espejo, V.O. and Manjarrez, F. (1993) The Solubility of Nitrogen in the $\mathrm{CaO}-\mathrm{CaF}_{2}-\mathrm{Al}_{2} \mathrm{O}_{3}$ System and Its Relationship with Basicity. ISIJ International, 33, 48-52. https://doi.org/10.2355/isijinternational.33.48 